\title{
Analisis Fatigue pada Slewing Tower Level Luffing Crane Berbasis Metode Elemen Hingga
}

\author{
Hanun A. R. Cahyono dan Julendra B. Ariatedja \\ Departemen Teknik Mesin, Fakultas Teknologi Industri, Institut Teknologi Sepuluh Nopember (ITS) \\ e-mail: ariatedja@me.its.ac.id
}

\begin{abstract}
Abstrak-Tidak hanya tegangan statis, pergerakan dalam mengangkat material secara vertikal maupun horizontal, menyebabkan tegangan dinamis yang juga turut berpengaruh terhadap ketahanan struktur crane. Tegangan dinamis berulang inilah yang dapat menyebabkan kelelahan (Fatigue) sehingga terjadi kegagalan seperti retak (Crack). Salah satunya adalah yang terjadi pada bagian tower Slewing Tower Level Luffing Crane produksi PT. Lelangon yang telah beroperasi selama 4 tahun di Tanjung Emas, Semarang, Jawa Tengah. Analisis dilakukan dengan pembebanan vertikal dan horizontal pada bagian tower berbasis metode elemen hingga. Analisis beban statis juga dilakukan terlebih dahulu untuk verifikasi beban desain dan memperoleh pembebanan yang akan digunakan pada tahap simulasi sebagai load condition. Dengan software berbasis Finite Element Method (FEM), simulasi static structural kemudian dilakukan pada bagian tower yang terbuat dari material High Strength Steel S355J2G3 dengan kondisi batas fixed support pada bagian dasar. Sebagai tahap proses validasi, hasil analisis melalui simulasi akan dibandingkan dengan perhitungan manual menggunakan aturan Palmgreen Miner untuk memperoleh fatigue life, berikut fatigue damage dan safety factor. Hasil dari penelitian ini didapatkan bahwa pada pembebanan secara vertikal dan horizontal, fatigue life dari Slewing Tower Level Luffing Crane ini jauh melebihi service life saat munculnya keretakan yaitu 3 tahun. Selain itu, fatigue life yang didapat juga masih berada di atas designed life 15 tahun. Hal ini diikuti dengan fatigue damage dan safety factor yang menunjukkan bahwa konstruksi crane aman dengan kondisi pembebanan tersebut. Hasil ini menjadi bukti bahwa kegagalan akibat fatigue secara vertikal maupun horizontal tidak akan terjadi hingga melebihi designed life. Sehingga, kegagalan berupa crack yang terjadi bukan disebabkan oleh fatigue.
\end{abstract}

Kata Kunci-Fatigue Damage, Fatigue Life, Metode Elemen Hingga, Safety Factor, Slewing Tower Level Luffing Crane.

\section{PENDAHULUAN}

$\mathrm{S}$ ECARA umum, beban yang bekerja pada Crane dapat dianalisis sebagai tegangan statis. Namun pergerakan dalam mengangkat material, baik secara vertikal maupun horizontal, menyebabkan tegangan dinamis juga turut berpengaruh terhadap ketahanan struktur crane. Walaupun tidak begitu besar, tegangan dinamis berulang inilah yang dapat menyebabkan kelelahan (Fatigue) sehingga timbul retak. Fatigue sendiri merupakan penyebab kerusakan sebuah mesin maupun struktur sebanyak 50\%-90\% [1]. Contohnya yaitu terjadi pada salah satu Slewing Tower Level Luffing Crane milik PT. Pelindo III yang beroperasi di Tanjung Emas, Semarang, Jawa Tengah. Crane produksi PT. Lelangon ini sehari-hari digunakan untuk memindahkan kayu gelondongan sejak tahun 2014. Namun pada tahun 2017, ditemukan perambatan retak di daerah hulu tower.

Oleh karena itu, analisa fatigue sangat penting dilakukan karena fatigue merupakan penyebab paling sering terjadi dan berbahaya dalam kegagalan struktur. Sebelum memasuki tahap simulasi, analisa tegangan statis terlebih dahulu dilakukan secara manual untuk verifikasi data beban desain. Selanjutnya, tahap analisis dilakukan menggunakan software berbasis Finite Element Method (FEM) . Berdasarkan olahan data tegangan akibat beban yang bekerja, melalui proses simulasi akan diperoleh estimasi usia lelah (Fatigue life), kerusakan (Fatigue damage), dan faktor keamanan (Safety factor). Tahap validasi dilakukan dengan membandingkan hasil simulasi dengan perhitungan manual, salah satunya menggunakan aturan Palmgreen Miner. Sehingga, bisa ditentukan apakah fatigue merupakan penyebab utama terjadinya kegagalan atau tidak.

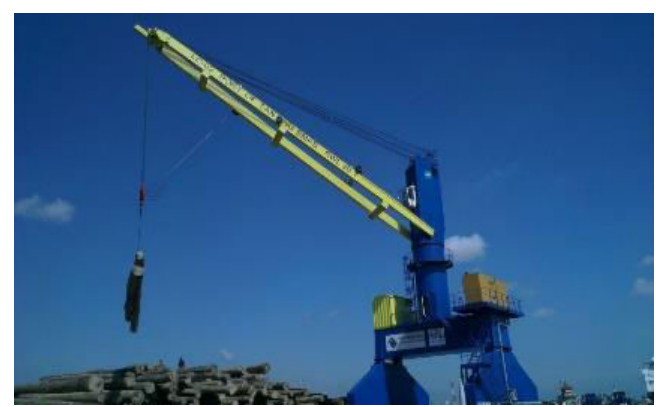

Gambar 1. Slewing Tower Level Luffing Crane yang Menjadi Objek Penelitian

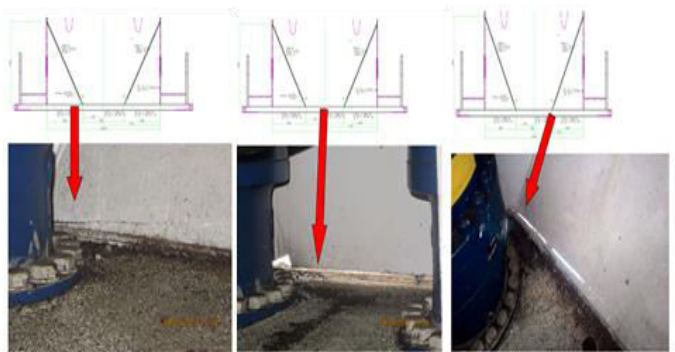

Gambar 2. Posisi Retak pada Slewing Tower Level Luffing Crane.

Penelitian ini betujuan untuk memperoleh fatigue life, fatigue damage, dan safety factor dari Slewing Tower Level Luffing Crane. Dari hasil tersebut, dapat ditentukan apakah fatigue merupakan penyebab utama terjadinya kegegalan berupa crack pada bagian tower. 


\section{II.METODE PENELITIAN}

\section{A. Objek Penelitian}

Seluruh tahap analisis yang dilakukan, baik simulasi maupun hand calculation difokuskan pada bagian tower dari Slewing Tower Level Luffing Crane. Kemudian, dilakukan permodelan bagian tower seperti yang terlihat di bawah ini:

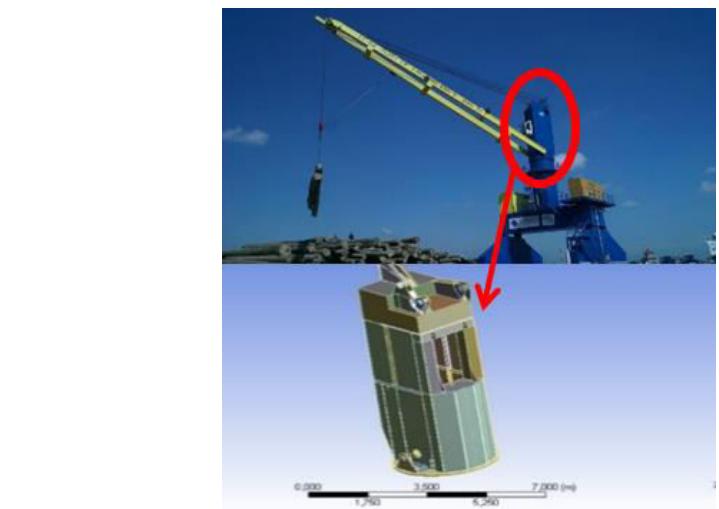

Gambar 3. Model geometri bagian tower.

Untuk menyederhanakan dan memfokuskan proses simulasi, model geometri yang telah dibuat disederhanakan. Penyederhanaan dilakukan dengan mengurangi ketinggian model tower dari 9,714 meter menjadi 1,276 meter.

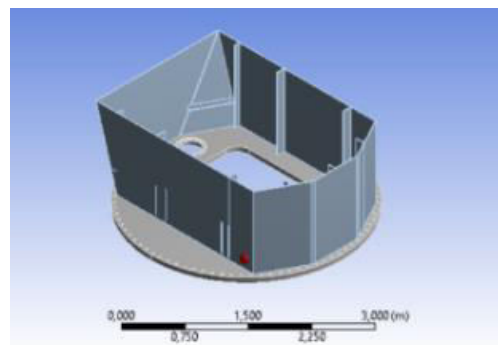

Gambar 4. Model Geometri Bagian Tower Setelah Disederhanakan

Kondisi batas yang diberikan pada objek analisa adalah tumpuan fixed support pada dasar tower. Hal ini dilakukan agar tidak terjadi perpindahan tower ketika diberikan pembebanan.

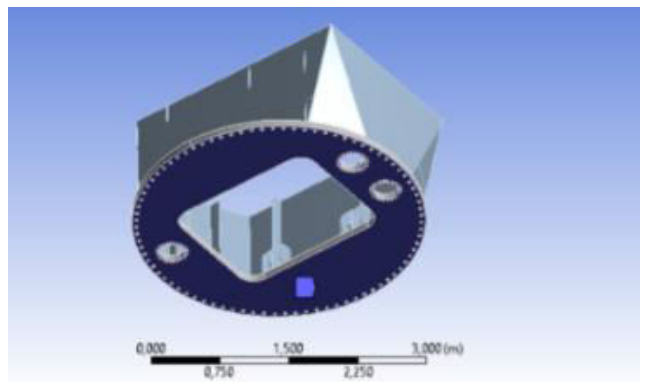

Gambar 5. Pemberian Kondisi Batas Fixed Support pada Dasar Tower

Bagian tower dari Slewing Tower Level Luffing Crane yang akan dianalisa menggunakan material High Strength Steel S355J2G3. Jenis material ini adalah baja struktur non-alloy yang merupakan bagian dari standar Eropa untuk baja struktur yaitu EN 10025:2004. Properti material dan S-N curve baja S355J2G3 dapat dilihat pada Tabel 1:
Tabel 1.

Properti High Strength Steel S355J2G3

\begin{tabular}{|rl|}
\hline \multicolumn{2}{|c|}{ Properties } \\
\hline Name: & 1.0570 (S355J2G3) \\
Model type: & Linear Elastic Isotropic \\
Default failure & Max von Mises Stress \\
criterion: & \\
Yield strength: & $315 \mathrm{~N} / \mathrm{mm}^{\wedge} 2$ \\
Tensile strength: & $490 \mathrm{~N} / \mathrm{mm}^{\wedge} 2$ \\
Elastic modulus: & $210000 \mathrm{~N} / \mathrm{mm}^{\wedge} 2$ \\
Poisson's ratio: & 0.28 \\
Mass density: & $7.8 \mathrm{~g} / \mathrm{cm}^{\wedge} 3$ \\
Shear modulus: & $79000 \mathrm{~N} / \mathrm{mm}^{\wedge} 2$ \\
Thermal expansion & $1.1 \mathrm{e}-005 /$ Kelvin \\
coefficient: & \\
\hline
\end{tabular}

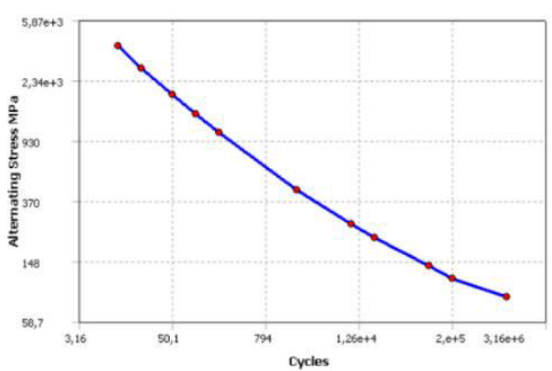

Gambar 6. S-N Curve High Strength Steel S355J2G3 [2].

Properti material ini kemudian dimasukkan ke dalam Engineering Data pada software ANSYS Workbench 18.0 untuk tahap simulasi.

\section{B. Analisis Beban Statis}

Tahap analisis beban statis dilakukan secara vertikal maupun horizontal dengan hand calculation. Pembebanan secara vertikal terdiri dari beban angkat kayu tongkang, berat $j i b$, dan gaya sentrifugal [3]. Analisis statis secara vertikal dilakukan dalam 2 tahap, yaitu saat proses pengengkutan beban maksimum dan juga kondisi tanpa beban. Hal ini dilakukan untuk mendapatkan tegangan Equivalent Von-Mises dari kedua kondisi sebagai tegangan maksimum dan minimum cycle.

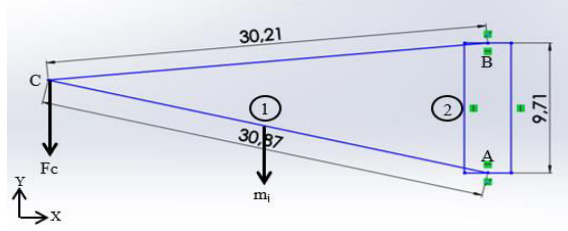

Gambar 7. Beban Angkat Kayu Tongkang dan Berat Jib.

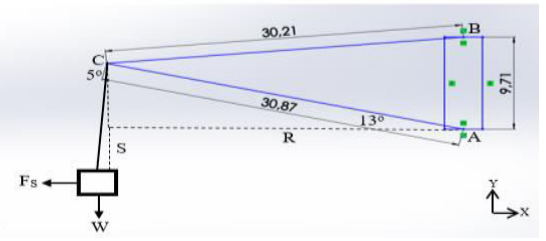

Gambar 8. Gaya sentrifugal.

Sedangkan pada pembebanan horizontal terdapat gaya dorong angin dan juga gaya tangensial yang bekerja pada bagian $j i b$. Secara horizontal, gaya dorong angin beserta gaya tangensial pada $j i b$ bekerja sekaligus secara bergantian dari arah yang berlawanan. Sehingga, pembebanan menghasilkan tegangan Equivalent Von-Mises maksimum dan minimum yang berkebalikan arah namun sama besar (Fully reversed). 


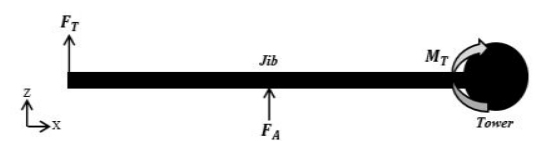

Gambar 9. Gaya dorong angin dan gaya tangensial (tampak atas).

Analisis beban statis ini bertujuan untuk verifikasi beban desain dan juga untuk mendapatka gaya reaksi yang bekerja pada bagian tower untuk selanjutnya digunakan dalam taham simulasi.

Dari hasil yang dapat, didapatkan tabel 1 sebagai tabel verifikasi beban desain.

Tabel 2.

Perbandingan Beban Desain dan Hasil Perhitungan Beban Statis

\begin{tabular}{|c|c|c|c|c|}
\hline Tinjauan & $\begin{array}{c}\text { Data Desain } \\
(K N)\end{array}$ & $\begin{array}{c}\text { Hasil } \\
\text { Perhitungan } \\
\text { dengan Beban } \\
\text { Maksimal }(K N)\end{array}$ & $\begin{array}{c}\text { Hasil } \\
\text { Perhitungan } \\
\text { tanpa Beban } \\
\text { Angkat }(K N)\end{array}$ & Keterangan \\
\hline Tilting Moment & 10700 & 9129,43 & 2345,931 & Aman \\
\hline Vertical Load & 800 & 336,925 & 137 & Aman \\
\hline Lateral Force & 50 & 0 & 0 & Aman \\
\hline
\end{tabular}

Selain itu, didapat juga gaya-gaya yang akan digunakan sebagai kondisi pembebanan pada tahap simulasi sebagi berikut:

Tabel 3.

Beban yang Bekerja secara Vertikal dan Horizontal

\begin{tabular}{|cccc|}
\hline \multirow{2}{*}{ Pembebanan } & \multicolumn{2}{c}{ Vertikal } & \multirow{2}{*}{ Horizontal } \\
\cline { 2 - 3 } & Beban Maksimal & Tanpa Beban & \\
\hline Gaya Vertikal Fby (KN) & 49,2 & 12,57 & 0 \\
\hline Gaya Horizontal Fbx (KN) & 946,58 & 241,5 & 0 \\
\hline Gaya Sentrifugal Fs (KN) & 6,59 & 0 & 0 \\
\hline Gaya Angin FA (KN) & 0 & 0 & 8,639 \\
\hline Gaya Tangensial FT (KN) & 0 & 0 & 0,722 \\
\hline
\end{tabular}

Pada load condition, gaya diletakkan pada posisi yang sebenarnya terhadap permukaan atas geometri yang telah disederhanakan menggunakan Remote Force.

\section{Meshing}

Convergence test dilakukan dengan variasi ukuran elemen pada beberapa metode meshing. Dari hasil yang didapat, Average Mesh Metrics yang didapat sudah melebihi 0,5 dengan perbedaan antar metode meshing sangat tipis. Maka selanjutnya, metode meshing dipilih berdasarkan batas nilai maksimal error $2 \%$ dengan waktu proses yang paling minimal. Oleh karena itu, dipilih Size Function Adaptive, Relevance Center Fine, Span Angle Coarse, dan ukuran elemen $27 \mathrm{~mm}$ sebagai metode yang digunakan dalam simulasi.

Tabel 4.

Metode Meshing yang Digunakan pada Simulasi
\begin{tabular}{|cc|}
\hline \multicolumn{2}{|c|}{ Metode Meshing } \\
\hline Size Function & Adaptive \\
\hline Relevance Center & Fine \\
\hline Span Angle & Coarse \\
\hline Element size (mm) & 27 \\
\hline Nodes & 245980 \\
\hline Elements & 84996 \\
\hline Average Mesh Metrics & 0,61533 \\
\hline
\end{tabular}

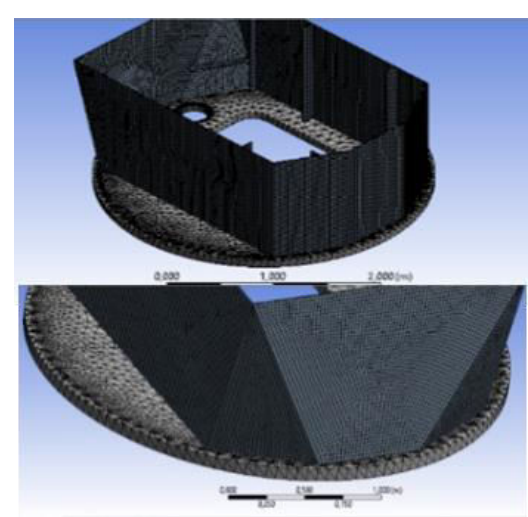

Gambar 10. Meshing pada bagian tower.

\section{Tahap Validasi}

Hasil yang didapat dari proses simulasi kemudian dilakukan proses validasi dengan perhitungan teoritis fatigue life berdasarkan aturan Palmgreen Miner berikut fatigue damage dan safety factor [4]. Aturan Palmgreen Miner yang merupakan teori kegagalan kumulatif dapat dirumuskan sebagai berikut:

$$
\begin{gathered}
D=\frac{n}{N} \\
D=\sum_{1}^{i} \frac{n_{i}}{N_{i}}=1 \\
L_{f}=\frac{1}{D}=\frac{1}{\sum_{1}^{i} \frac{n_{i}}{N_{i}}}
\end{gathered}
$$

Fatigue damage dapat diperoleh dari perbandingan Designed life $\left(L_{D}\right)$ dan fatigue life $\left(L_{f}\right)$ hasil analisis. Nilai fatigue damage yang lebih besar dari 1 menunjukkan bahwa kegagalan pada struktur akan terjadi sebelum mencapai Designed life.

$$
F D=\frac{L_{D}}{L_{f}}
$$

Sedangkan untuk menghitung safety factor, hasil prediksi Fatigue life dibagi dengan umur pemakaian atau service life $\left(L_{S}\right)$ obyek tersebut.

$$
S F=\frac{L_{f}}{L_{S}}
$$

Dengan:

D : Kerusakan dalam satu tahun

$n_{i}$ :Jumlah siklus pada rentang tegangan yang bekerja (Cycle)

$N_{i}$ :Jumlah siklus pada rentang tegangan yang diizinkan sesuai diagram S-N (Cycle)

$L_{f}:$ Fatigue life atau umur Lelah (Tahun)

$L_{D}$ : Designed life atau umur desain (Tahun)

$L_{S}$ : Service life atau umur operasi (Tahun)

\section{HASIL DAN PEMBAHASAN}

\section{A. Hasil Simulasi}

1. Analisis Fatigue Beban Vertikal

Pada analisis fatigue beban vertikal, dilakukan 2 kali simulasi yaitu saat crane mengangkat beban maksimal dan juga tanpa beban. 1 siklus pembebanan meliputi 1 proses pemindahan beban maksimal, dari pengangkatan hingga penurunan beban. Oleh karena itu, diperlukan analisa statis dengan tegangan Equivalent Von-Mises terbesar dari kedua 
proses tersebut sebagai hasil untuk kemudian didapatkan ratio (R) tegangan siklik yang bekerja pada tower Slewing Tower Level Luffing Crane ini.

Dengan load condition yang diberikan sesuai dengan hasil perhitungan secara statis saat mengangkat beban maksimal, didapat hasil distribusi tegangan Equivalent Von-Mises sebagai berikut:

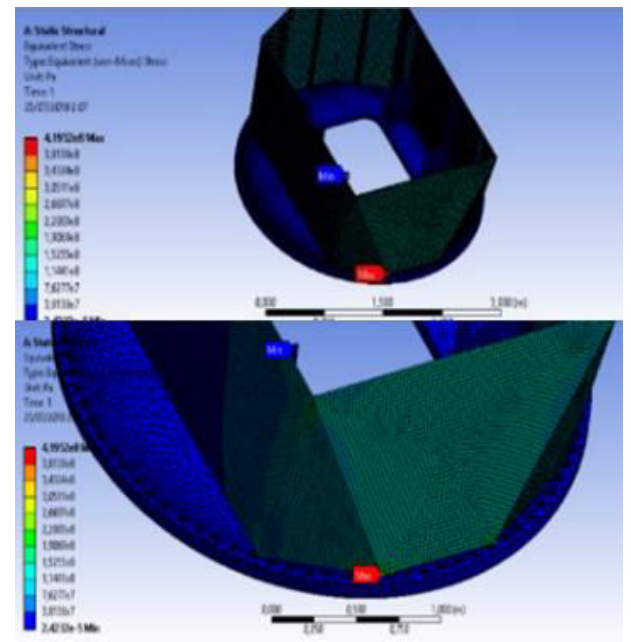

Gambar 11. Distribusi Tegangan Equivalent Von-Mises dengan Beban Maksimum

Tabel 5.

Tegangan Equivalent Von-Mises dengan Beban Maksimum

\begin{tabular}{|cc|}
\hline \multicolumn{2}{|c|}{ Tegangan Equivalent Von-Mises (Mpa) } \\
\hline Maksimum & Minimum \\
\hline 106,95 & $5,82 \mathrm{E}-06$ \\
\hline
\end{tabular}

Selanjutnya dengan pembebanan yang berbeda, berikut adalah hasil distribusi tegangan Equivalent Von-Mises ketika tidak ada beban yang diangkat:

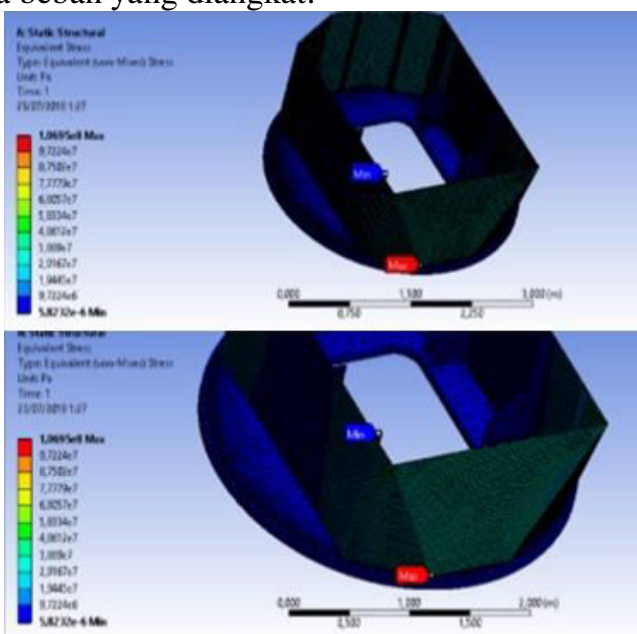

Gambar 12. Distribusi tegangan equivalent von-mises tanpa beban.

Tabel 6.

Tegangan Equivalent Von-Mises tanpa Beban

\begin{tabular}{|cc|}
\hline \multicolumn{2}{|c|}{ Tegangan Equivalent Von-Mises (Mpa) } \\
\hline Maksimum & Minimum \\
\hline 419,52 & $2,42 \mathrm{E}-05$ \\
\hline
\end{tabular}

Setelah didapat hasil distribusi tegangan Equivalent VonMises dari 2 kondisi pembebanan tersebut, dilakukan perhitungan ratio $(\mathrm{R})$ tegangan siklik. Tegangan maksimum saat pembebanan maksimal menjadi tegangan maksimum, sedangan tegangan maksimum saat tidak ada beban menjadi tegangan minimum. Perhitungan dilakukan seperti di bawah ini:

$$
R=\frac{\sigma_{\min }}{\sigma_{\max }}=\frac{106,95(M P a)}{419,52(M P a)}=0,254934
$$

Sehingga, didapat tegangan siklik berdasarkan ratio (R) sebagai berikut:

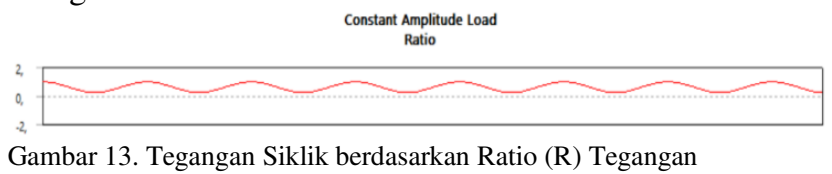

Selanjutnya, analisis fatigue dilakukan pada simulasi pembebanan maksimal dengan menggunakan bar solution Fatigue Tool dan loading type Ratio. Ratio (R). Tegangan siklik hasil perhitungan di atas dimasukkan kedalam bar Loading dan didapat hasil fatigue life minimum 797530 cycles. Distribusi fatigue life yang didapat adalah sebagai berikut:
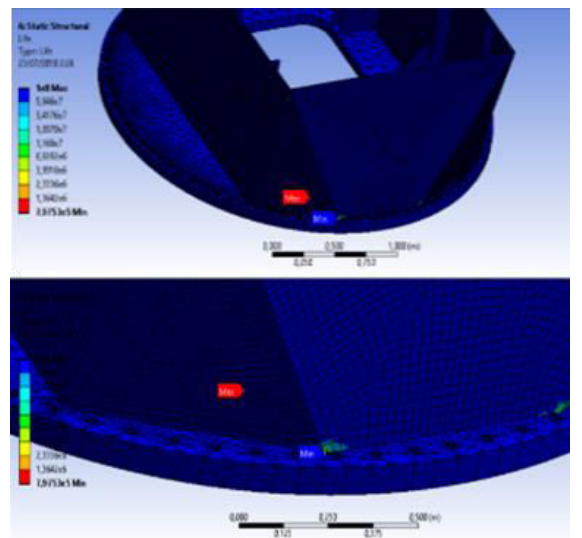

Gambar 14. Distribusi Fatigue Life

Yang kedua, fatigue damage terbesar yang didapat adalah 0,56438 dengan distribusi sebagai berikut:

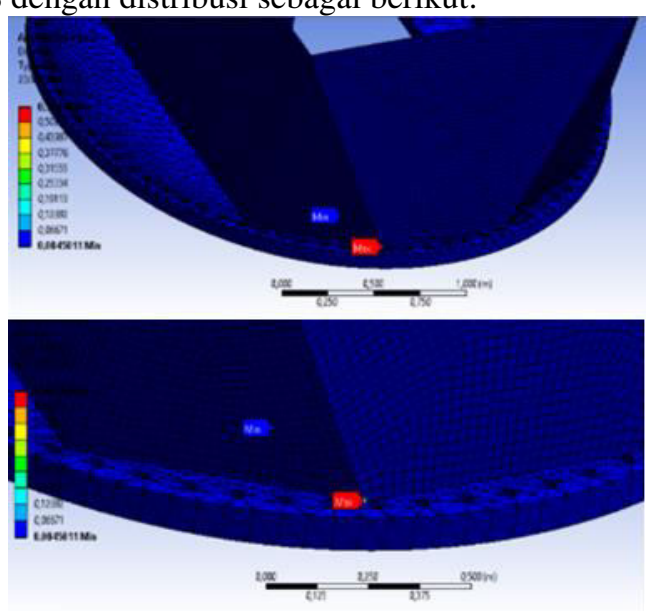

Gambar 15. Distribusi Fatigue Damage. 
Kemudian, didapat juga safety factor terkecil yaitu 1,0925 dengan distribusi sebagai berikut:

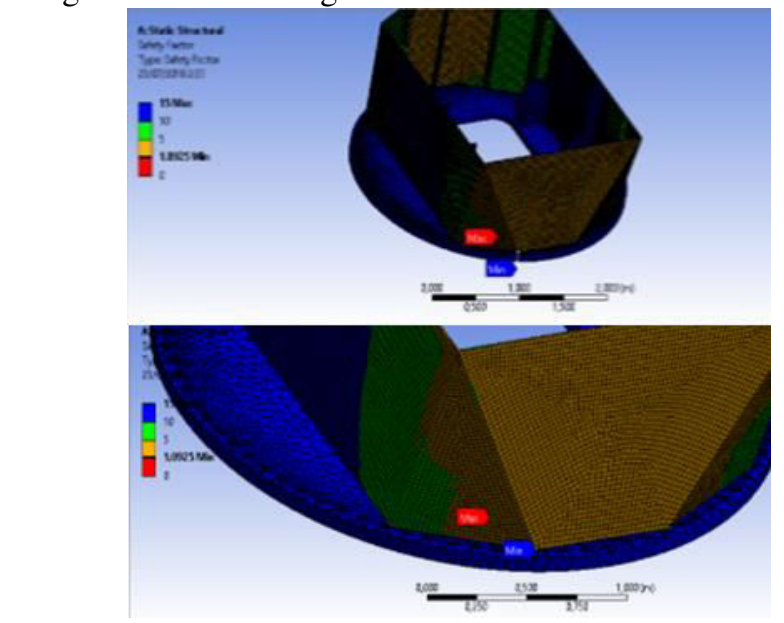

Gambar 16. Distribusi Safety Factor

Agar lebih sederhana, berikut adalah rangkuman hasil analisis fatigue secara vertikal:

Tabel 7.

Hasil Analisis Fatigue Beban Vertikal

\begin{tabular}{|cc|}
\hline \multicolumn{2}{|c|}{ Hasil Analisa } \\
\hline Fatigue life & 797530 \\
\hline Fatigue damage & 0,56438 \\
\hline Safety factor & 1,0925 \\
\hline
\end{tabular}

2. Analisa Fatigue Beban Horizontal

Berbeda dengan analisis fatigue beban vertikal, pada pembebanan horizontal digunakan loading type Fully Reversed karena arah dan besar momen maksimum yang bekerja pada jib sama. Oleh karena itu, analisis dilakukan hanya pada 1 kondisi pembebanan maksimal. Namun, analisis statis untuk memperoleh tegangan Equivalent Von-Mises terbesar tetap dilakukan sebagai dasar proses analisis fatigue selanjutnya.

Dengan metode yang sama, secara horizontal didapat keseluruhan hasil sebagai berikut:

Tabel 8.

Hasil Analisis Fatigue Beban Horizontal

\begin{tabular}{|c|c|}
\hline \multicolumn{2}{|c|}{ Hasil Analisa } \\
\hline Fatigue life & 1299000 \\
\hline Fatigue damage & 0,34651 \\
\hline Safety factor & 1,3508 \\
\hline
\end{tabular}

\section{B. Hasil Validasi}

Sesuai data operasional Slewing Tower Level Luffing Crane yang didapat dari PT. Lelangon, diketahui:

- 1 cycle $=5 \mathrm{menit} /$ cycle

- Rata-rata cycle/jam

$=60$ menit $/ 1 \mathrm{jam}: 5 \mathrm{menit} / \mathrm{cycle}$

$=12$ cycles $/ \mathrm{jam}$

- Rata-rata cycle/hari

$=12$ cycle/jam x $18 \mathrm{jam} / \mathrm{hari}$

$=216$ cycles $/$ hari

- Rata cycle/operasi
$=216 \mathrm{cycle} /$ hari $\mathrm{x} 6$ hari/operasi

$=1296$ cycles/operasi (Bongkar 2 tongkang)

Terdapat 3 kali down time untuk maintenance selama masingmasing 3 minggu, sehingga:

- Hari/tahun

$=365$ hari $-(9 \times 7$ hari $)$

$=302$ hari $/$ tahun

Terdapat waktu menunggu kapal selanjutnya datang selama 7 hari, sehingga 1 kali proses pembongkaran 2 tongkang terhitung total 13 hari/operasi.

- Rata-rata operasi/tahun

$=1$ operasi $/ 13$ hari x 302 hari/tahun

$=23,231$ operasi $/$ tahun

- Rata-rata cycle/tahun ( $n$ )

$=1296$ cycle/operasi $\mathrm{x} 23,231$ operasi/tahun

$=30107,077$ cycles $/$ tahun

Hasil rata-rata cycle/tahun inilah yang akan digunakan sebagai acuan dalam proses validasi menggunakan hand calculation.

1. Analisis Fatigue Beban Vertikal

a. Fatigue Life

Hasil dari simulasi menunjukkan fatigue life sebesar 797530 cycles di mana dalam satuan tahun yaitu:

$L=797530$ cycles $: 30107,077$ cycles $/$ tahun

$=26,49$ tahun

Sehingga berdasarkan hasil simulasi, fatigue life dari konstruksi Slewing Tower Level Luffing Crane ini mencapai 26,49 tahun. Sedangkan dengan aturan Palmgreen Miner, fatigue life dapat diperoleh dari perhitungan berikut:

- Mencari $\sigma_{a}$ Effective (Equivalent Alternating Stress) [5].

$\sigma_{\max }=419,52(\mathrm{MPa})$

$\sigma_{\min }=106,95(M P a)$

$S_{u}=490(M P a)$

$\sigma_{a}=\frac{\left(\sigma_{\max }-\sigma_{\min }\right)}{2}=\frac{(419,52-106,95)}{2}=156,29(\mathrm{MPa})$

$\sigma_{m}=\frac{\left(\sigma_{\max }+\sigma_{\min }\right)}{2}=\frac{(419,52+106,95)}{2}=263,24(M P a)$

$\sigma_{a}$ Effective (Equivalent Alternating Stress) $=\sigma_{a}\left(\frac{s_{u}{ }^{2}}{S_{u}{ }^{2}-\sigma_{m}{ }^{2}}\right)$

$\sigma_{a}$ Effective $=156,29\left(\frac{490^{2}}{490^{2}-263,24^{2}}\right)(M P a)$

$\sigma_{a}$ Effective $=154,58\left(\frac{240100}{240100-69292,67}\right)(M P a)$

$\sigma_{a}$ Effective $=154,58 \times 1,406(M P a)$

$\sigma_{a}$ Effective $=219,69(\mathrm{MPa})$

- Mencari cycle dari S-N Curve material

Pada tahap ini, perlu dilakukan interpolasi untuk mengatahui cycle pada $\sigma_{a}$ Effective berdasarkan S-N Curve material High Strength Streel S355J2G3 seperti di bawah ini:

$\frac{250-219,69}{500000-N}=\frac{219,69-205}{N-1000000}$

$\frac{500000-N}{30,314}=\frac{219,69-1000000}{N-69}$

$\frac{30,314}{500000-N}=\frac{14,6900000000}{N-100000}$

$30,314 N-30314000=7345000-14,69 N$

$45 N=37659000$

$N=836866,67$ cycles

- Perhitungan dengan aturan Palmgreen Miner

$D=\frac{n}{N}=\frac{30107,077}{836866,67}=0,036$ 
$L=\frac{1}{D}=\frac{1}{0,036}=27,8$ tahun

b. Fatigue Damage

Fatigue damage $=\frac{\text { Design life }}{\text { Estimated fatigue life }}$

Fatigue damage $=\frac{15 \text { tahun }}{27,8 \text { tahun }}$

Fatigue damage $=0,5396$

\section{c. Safety Factor}

Sejak 2014, saat ini usia Slewing Tower Level Luffing Crane (Service life) mencapai 4 tahun.

Safety factor $=\frac{\text { Estimated fatigue life }}{\text { Service life }}$

Safety factor $=\frac{27,8 \text { tahun }}{4 \text { tahun }}$

Safety factor $=6,949$

Tabel 9.

Hasil Analisis Fatigue Beban Vertikal

\begin{tabular}{|cc|}
\hline \multicolumn{2}{|c|}{ Hasil Analisa } \\
\hline Fatigue life & 27,8 tahun \\
\hline Fatigue damage & 0,5396 \\
\hline Safety factor & 6,949 \\
\hline
\end{tabular}

2. Analisis Fatigue secara Horizontal

Dengan metode perhitungan yang sama, didapat hasil analisis fatigue beban horizontal sebagai berikut:

Tabel 10.

Hasil Analisis Fatigue Beban Horizontal

\begin{tabular}{|cc|}
\hline \multicolumn{2}{|c|}{ Hasil Analisa } \\
\hline Fatigue life & 54,81 tahun \\
\hline Fatigue damage & 0,27368 \\
\hline Safety factor & 13,702 \\
\hline
\end{tabular}

\section{PENUTUP}

\section{A. Kesimpulan}

Berdasarkan analisis fatigue yang telah dilakukan terhadap Slewing Tower Level Luffing Crane, didapat total hasil seperti yang ditunjukkan pada Tabel 11:

Pada fatigue safety factor, terdapat perbedaan yang sangat besar antara hasil simulasi dan hand calculation. Perbedaan ini disebebkan karena safety factor hasil perhitungan merupakan safety factor analisis. Semakin lama penundaan proses analisis, service life dari objek semakin besar hingga mencapai fatigue life yang diestimasi. Sehingga, safety factor akan terus mengecil hingga mencapai angka satu.

Baik secara vertikal maupun horizontal, estimasi fatigue life lebih besar daripada usia Slewing Tower Level Luffing Crane ini saat terjadi crack yaitu 3 tahun dan bahkan melebihi designed life selama 15 tahun. Hasil ini juga didukung oleh fatigue damage dan safety factor yang menunjukkan bahwa konstruksi crane aman dengan pembebanan tersebut. Oleh karena itu, fatigue bukan merupakan penyebab terjadinya kegagalan crack yang terjadi.

Tabel 11.

Hasil Analisis Fatigue Secara Keseluruhan

\begin{tabular}{|c|c|c|c|}
\hline \multirow{2}{*}{ Analisis } & \multicolumn{2}{|c|}{ Hasil } \\
\cline { 2 - 4 } & & Simulasi & Hand calculation \\
\hline \multirow{3}{*}{ Secara vertikal } & Fatigue life & 26,49 tahun & 27,8 tahun \\
\cline { 2 - 4 } & Fatigue damage & 0,56438 & 0,5396 \\
\cline { 2 - 4 } & Safety factor & 1,0925 & 6,949 \\
\hline \multirow{3}{*}{ Secara horizontal } & Fatigue life & 43,15 tahun & 54,81 tahun \\
\cline { 2 - 4 } & Fatigue damage & 0,34651 & 0,27368 \\
\cline { 2 - 4 } & Safety factor & 1,3508 & 13,702 \\
\hline
\end{tabular}

\section{B. Saran}

Adanya interpolasi pada data semi-log S-N curve menyebabkan cycle yang didapat tidak akurat. Oleh karena itu, sebaiknya dilakukan pembacaan S-N curve secara manual. Selain itu, Parameter lain yang bekerja pada Slewing Tower Level Luffing Crane seperti pengaruh getaran dan data rekam histogram beban aktual sesuai keadaan di lapangan sangat diperlukan untuk hasil analisis fatigue yang lebih akurat.

\section{DAFTAR PUSTAKA}

[1] A. Abrianto, “Diktat Kuliah Kelelahan Logam,” Jakarta, 2007.

[2] F. Solfins and F. Report, "Mechanical Analysis and Optimisation of Front Roller Assembly." 2010.

[3] Anonymous, "Cranes Transportation," Mechanical engineering Department Carlos III University. [Online]. Available: http://ocw.uc3m.es/ingenieria-mecanica/transportengineering/ingenieria-mecanica/transportengineering/transparencias/Cranes.pdf.

[4] Anonymous, "Analisis Fatigue Bab 6," digilib.itb.ac.id. [Online]. Available: http://digilib.itb.ac.id/files/disk1/629/jbptitbpp-gdlchairulamr-31418-7-2008ta-6.pdf.

[5] Awwaluddin and et al, "Analisa Fatigue Life pada Struktur Dudukan Bogie pada Perancangan dan Pengembangan Monorail UTM-125 Kapasitas 24 Ton Menggunakan Metode Elemen Hingga," Jakarta. 